\title{
Pengaruh Strategi Pemasaran dan Pelayanan terhadap Kepuasan Mahasiswa pada STIE Mahaputra Riau
}

\author{
Firmansyah \\ Sekolah Tinggi Ilmu Ekonomi (STIE) Mahaputra Riau \\ e-mail: firmansyahimansyah@yahoo.co.id
}

\begin{abstract}
The purpose of this study is to determine the effect of marketing strategies on student satisfaction at STIE Mahaputra Riau, to determine the effect of service on student satisfaction at STIE Mahaputra Riau. The results of this study are that marketing strategies affect student satisfaction at STIE Mahaputra Riau, service influences student satisfaction at STIE Mahaputra Riau, and the coefficient of determination is 92,\% which means that student satisfaction can be explained by 92\% marketing and service strategies while the rest is influenced by other factor.
\end{abstract}

Keywords: marketing strategy, service and student satisfaction

\section{PENDAHULUAN}

Kepuasan merupakan bagian yang terpenting bagi sebuah perguruan tinggi, baik perguruan tinggi negeri maupun perguruan tinggi swasta. Kepuasan merupakan rasa senang atas suatu barang di miliki atau dipergunakan baik dalam segi jasa maupun produk. Pada saat sekarang ini, jumlah perguruan tinggi sebakin lama semakin banyak dikarenakan semakin sadarnya masyarakat akan perlunya pendidikan tersebut untuk meningkatkan kondisi ekonomi atau memperbaiki kondisi ekonomi tersebut. Perguruan tinggi dalam meningkatkan kinerja nya salah satunya yakni memberikan rasa puas bagi penggunanya, salah satunya dengan strategi yang baik dengan menggunakan bauran pemasaran dan melalui peningkatan pelayanan pada pengguna dengan kualitasnya.

Menurut Tjiptono (2008:6), bahwa strategi pemasaran sebagai alat fundamental yang direncanakan untuk mencapai tujuan perusahaan dengan cara mengembangkan keunggulan bersaing yang berkesinambung melalui pasar yang dimasuki dan program pemasaran yang digunakan untuk melayani pasar sasaran tersebut. Dengan banyaknya perguruan tinggi di Provinsi Riau segala kemampuanya memberikan berbagai strategi dan layanan yang terbaik bagi mahasiswa agar mahasiswa atau pengguna merasa puas.
Menurut Tjiptono (2012:164) bahwa kualitas pelayanan adalah karateristik atau atribut obyektif yang dapat dikuantitatifkan dan dapat diukur. Perbedaan dalam kualitas mencerminkan perbedaan dalam jumlah beberapa unsur atau atribut yang dimiliki produk.

Andaiyani (2015:2) menyatakan bahwa adanya hubungan antara stategi pemasaran dengan kepuasan pelanggan. Ia menyatakan bahwa dimensi-dimensi strategi produk, harga, promosi, lokasi dan fasilitas dapat mempengaruhi variabel strategi pemasaran diuji secara parsial terhadap keputusan pelanggan, maka hal ini terbukti bahwa variabel strategi pemasaran berpengaruh secara signifikan terhadap variabel kepuasa pelanggan.

Menurut Anderson (dalam Anatan, 2010:70), adanya hubungan antara kualitas pelayanan dengan kepuasan pelanggan. Ia menyatakan bahwa upaya perbaikan kualitas pelayanan akan bisa menghasilkan kepuasan konsumen, oleh karena itu hubungan tersebut harus ditingkatkan.

Perumusan masalah pada penelitian ini adalah: (a) Apakah strategi pemasaran berpengaruh terhadap kepuasan mahasiswa pada STIE Mahaputra Riau; dan, (b) Aapakah pelayanan berpengaruh terhadap kepuasan mahasiswa pada STIE Mahaputra Riau. 
Tujuan penelitian ini yakni untuk mengetahui pengaruh dari strategi pemasaran terhadap kepuasan mahasiswa pada STIE Mahaputra Riau, serta untuk mengetahui pengaruh pelayanan terhadap kepuasan mahasiswa pada STIE Mahaputra Riau.

\section{Kajian Pustaka dan Pengembangan Hipotesis}

Menurut Tjiptono (2012:54), kepuasan pelanggan adalah konsep sentral dalam wancana bisnis dan manajemen. Konsekuensi kepuasan/ketidakpuasan pelanggan sangat krusial bagi kalangan bisnis, pemerintah, dan juga konsumen, bagi bisnis kepuasan dipandang sebagai salah satudimensi kinerja pasar. Peningkatan kepuasan pelanggan berpotensi mengarah pada pertumbuhan penjualan penjualan jangka panjang dan jangka pendek, serta pangsa pasar sebagai hasil penilaian ulang; sementara itu ketidakpuasan pelanggan memunculkan sejumlah resiko, seperti boikot atau protes dari lembaga konsumen, komplain pelanggan, ataupun intervensi pemerintah.

Tjiptono dan Chandra (2011:292) menyatakan kata 'Kepuasan (Satisfaction)' berasal dari bahasa Latin "satis" (artinya cukup baik, memadai) serta "facio" (melakukan atau membuat). Kepuasan bisa diartikan sebagai "upaya pemenuhan sesuatu" atau "membuat sesuatu memadai". Supriyanto dan Ernawaty (2010:310) menyatakan bahwa kepuasan pelanggan adalah suatu keadaan ketika kebutuhan, keinginan dan harapan pasien dapat dipenuhi melalui produk/jasa yang dikonsumsi. Oleh karena itu, kepuasan pasien adalah rasio kualitas yang dirasakan oleh pasien dibagi dengan kebutuhan, keinginan dan harapan pasien.

Menurut Supriyanto dan Ernawaty (2010:316), kepuasan pasien adalah hasil suatu evaluasi (pembandingan) dari apa yang didapat dengan apa yang diharapkan, bukan suatu sikap (rasa menyukai sesuatu atau tidak menyukai tanpa unsur pembandingan). Menurut Howard dan Sheth (dalam Tjiptono, 2014:353), kepuasan pelanggan adalah situasi kognitif pembeli yang berkenaan dengan kesepadanan atau ketidaksepadanan antara hasil yang didapatkan dibandingkan dengan pengorbanan yang dilakukan.

Menurut Wijaya (2011:6) bahwa pada dasarnya tujuan perusahaan adalah upaya menciptakan kepuasan bagi para pelanggan. Terciptanya kepuasan pelanggan dapat memberikan beberapa manfaat, diantaranya hubungan antara pihak perusahaan dan para pelanggannya harmonis, menjadikan dasar yang baik bagi pembeli ulang dan terciptanya loyalitas pelanggan, yang akan membentuk rekomendasi dari mulut ke mulut yang menguntungkan bagi perusahaan.

Supriyanto dan Ernawaty (2010:326) menyatakan bahwa ada beberapa faktor yang berpengaruh pada kepuasan konsumen. Secara garis besar, ada lima kategori, yaitu:

1. Mutu Produk (product quality), yaitu bagaimana konsumen akan merasa puas atas produk barang yang digunakan? Beberapa dimensi yang yang membentuk kualitas atas produk barang adalah performance, reliability, conformance, feature, dan lain-lain.

2. Mutu layanan (service quality), yaitu bagaimana konsumen akan merasa puas atas jasa yang telah dikonsumsinya? Dimensi service quality yang dikenal dengan ServQual meliputi lima dimensi yaitu reliability, assurance, tangible, empathy dan responsiveness.

3. Faktor emosi (emotional factor), yaitu keyakinan dan rasa bangga terhadap produk/jasa yang digunakan dibandingkan dengan pesaing.

4. Harga (price), yaitu harga produk/jasa yang diukur dari value (nilai) manfaat dibandingkan biaya yang dikeluarkan konsumen. Harga diukur dengan indikator perceived best value, yaitu jumlah sampel yang merasakan jasa yang dipilih sebagai terbaik dibandingkan pesaing.

Tjiptono (2012:323) mengatakan bahwa ada beberapa faktor yang mempengaruhi kepuasan pelanggan, diantaranya adalah sebagai berikut:

1. Faktor Persaingan.

Reaksi pesaing terhadap perubahan harga merupakan salah satu faktor penting yang perlu dipertimbangkan oleh setiap 
perusahaan. Hal ini karena jika perubahan harga disamai oleh semua pesaing, maka sebenarnya tidak ada perubahan pangsa pasar. Dalam kasus ini, pengurangan harga tidak akan berdampak pada permintaan selektif. Oleh sebab itu, manajer pemasaran harus berusaha menentukan kemungkinann reasik penetapan harga pesaingan.

2. Faktor Biaya.

Struktur biaya perusahaan (biaya tetap dan biaya variabel) merupakan faktor pokok yang menentukan batas bahwa harga. Artinya, tingkat harga menimal harus bisa menutup biaya (setidaknya biaya variabel). Harga yang murah akan menyebabkan penurunan biaya rata-rata jika penurun harga tersebut bisa menaikan volume penjualan secara signifikan, ini dikarenakan peningkatan volume berdampak pada berkurangnya biaya per unit. Oleh sebab itu, manfaat skala ekonomis akan sangat besar jika biaya tetap mencerminkan porsi yang besar dari biaya total.

\section{Faktor Lini Produk.}

Dalam banyak kasus, penetapan harga sebuah produk bisa berpengaruh terhadap penjualan produk lainya yang dihasilkan oleh perusahaan yang sama. Elastitas silang harga merupakan hubungan yang terjadi jika perubahan harga sebuah produk mempengaruhi volume penjualan produk kedua (selain berdampak pada penjualan produk pertama. Apabila kenaikan (atau penurunan) harga satu produk menyebabkan kenaikan (atau penurunan) penjualan produk kedua, makak kedua produk tersebut dikatakan bersifat subtitusi. Sementara jika kenaikan (penurunan) harga produk pertama menyebabkan penurunan (kenaikan) penjual produk kedua, maka kedua produk tersebut bersifat komplemeter.

Menurut Widya (2011:283), strategi pemasaran adalah proses pembuatan dan pemeliharaan suatu strategi yang menyesuaikan antara tujuan organisasi, kemampuan dan kesempatan pemasaran yang berubah. Ini bergantung pembuatan misi perusahaan yang jelas, tujuan yang mendukung, portofolio bisnis yang sehat strategi fungsional yang terkoordinasikan.

Menurut Tjiptono (2008:6), strategi pemasaran sebagai alat fundamental yang direncanakan untuk mencapai tujuan perusahaan dengan mengembangkan keunggulan bersaing yang berkesinambung melalui pasar yang dimasuki dan program pemasaran yang digunakan untuk melayani pasar sasaran tersebut.

Tjiptono (2012:74) menyatakan bahwa kualitas pelayanan adalah istilah kualitas itu sendiri mengandung berbagai macam penafsiran, karena kualitas memiliki sejumlah level: universal (sama di manapun), kultural (tergantung sistem nilai budaya), sosial (dibentuk oleh kelas sosial ekonomi, kelompok etnis, keluarga, teman sepergaulan), dan personal (tergantung preferensi atau selera setiap individu). Secara sederhana, kualitas bisa diartikan sebagai produk yang bisa cacat. Dengan kata lain, produk sesuai dengan standar (target, sasaran atau persyaratan yang bisa didefinisikan, diobservasi dan diukur) namun dengan definisi berbasis manufakur ini kurang relevan untuk sektor jasa.

Menurut Tjiptono (2012:164), kualitas pelayanan adalah karateristik atau atribut obyektif yang dapat dikuantitatifkan dan dapat diukur. Perbedaan dalam kualitas mencerminkan perbedaan dalam jumlah beberapa unsur atau atribut yang dimiliki produk. Sementara itu, Wyckof (dalam Tjiptono, 2014:268) menyatakan kualitas pelayanan atau kualitas jasa merupakan tingkat keunggulan yang diharapkan dan pengendalian atas keunggulan itu untuk memenuhi keinginan pelanggan.

Tjiptono (2012:323) mengatakan bahwa ada beberapa faktor yang dianggap mempengaruhi kualitas pelayanan, diantaranya adalah:

1. Mengupayakan agar aspek fisik jasa secara akurat mecerminkan jenis dan tingkat jasa yang diberikan

2. Menggunakan riset pasar dalam upaya menentukan filosofi jasa personal para pelanggan dan memanfaatkan informasi 
tersebut dalam proses perancangan dan penyampaian jasa.

3. Mendidik para pelanggan untuk upaya memahami peranan mereka peranan mereka dan menjalankan dengan baik.

4. Memanfaatkan riset pemasaran untuk mengetahui pengalaman sebelumnya yang dialami pelanggan dengan jasa serupa.

5. Memanfaatkan generasi jasa tanpa syarat untuk menyakinkan pelanggan mengenai pemulihan jasa.

6. Menginformasikan kepada pelanggan bila ketentuan jasa jauh lebih tinggi daripada yang umumnya diharapkan sehingga prediksi pelanggan terhadap penyampaian jasa di waktu mendatang tidak membumbung tinggi.

Gaspersz (dalam Herlambang, 2016:13) menyatakan bahwa aspek kualitas pelayanan meliputi dimensi-dimensi sebagai berikut:

a. Ketepatan waktu pelayanan berkaitan dengan waktu tunggu dan proses.

b. Kualitas pelayanan berkaitan dengan akurasi atau ketepatan pelayanan.

c. Kualitas pelayanan berkaitan dengan kesopanan dan keramahan pelaku bisnis.

d. Kualitas pelayanan berkaitan dengan tanggung jawab dalam penanganan keluhan pelanggan.

e. Kualitas pelayanan berkaitan dengan sedikit banyaknya petugas yang melayani serta fasilitas pendunkung lainnya.

f. Kualitas pelayanan berkaitan dengan lokasi, ruang tempat pelayanan, tempat parkir, ketersediaan informasi, dan petunjuk atau panduan lainnya.

g. Kualitas pelayanan berhubungan dengan kondisi lingkungan, kebersihan, ruang tunggu, fasilitas musik, AC, alat komunikasi, dan lain-lain.

Parasuraman, dkk. (dalam Lupiyoadi \& Hamdani, 2006:182) menyimpulkan bahwa terdapat lima dimensi kualitas pelayanan, sebagai berikut:

1. Berwujud (tangible), yaitu kemampuan suatu perusahaan dalam menunjukkan eksistensinya kepada pihak eksternal. Penampilan dan kemampuan sarana dan prasarana fisik perusahaan yang dapat diandalkan keadaan lingkungan sekitarnya merupakan bukti nyata dari pelayanan yang diberikan oleh pemberi jasa. Hal ini meliputi fasilitas fisik (contoh : gedung, gudang, dan lain-lain), perlengkapan dan peralatan yang digunakan (teknologi), serta penampilan pegawainya.

2. Keandalan (reliability), yaitu kemampuan perusahaan untuk memberikan pelayanan sesuai dengan yang dijanjikan secara akurat dan terpercaya. Kinerja harus sesuai dengan harapan pelanggan yang berarti ketepatan waktu, pelayanan yang sama untuk semua pelanggan tanpa kesalahan, sikap yang simpatik, dan dengan akurasi yang tinggi.

3. Ketanggapan (responsiveness), yaitu suatu kebijakan untuk membantu dan memberikan pelayanan yang cepat (responsif) dan tepat kepada pelanggan, dengan upaya menyampaikan informasi yang jelas. Membiarkan konsumen menunggu akan menimbulkan persepsi yang negatif dalam kualitas pelayanan.

4. Jaminan dan kepastian (assurance), yaitu pengetahuan, kesopansantunan, dan kemampuan para pegawai perusahaan untuk menumbuhkan rasa percaya para pelanggan kepada perusahaan. Hal ini meliputi beberapa komponen antara lain komunikasi, kredibilitas, keamanan, kompetensi dan sopan santun.

5. Empati (empathy), yaitu memberikan perhatian yang tulus dan bersifat individual atau pribadi yang diberikan kepada para pelanggan dengan berupaya memahami keinginan konsumen. Dalam hal ini, suatu perusahaan diharapkan memiliki pengertian dan pengetahuan tentang perilaku pelanggan, memahami kebutuhan pelanggan secara spesifik, serta memiliki waktu pengoperasian yang nyaman bagi pelanggan.

\section{Penelitian Terdahulu}

Firdaus dan Rahmawati (2017) meneliti tentang pengaruh bauran pemasaran, kualitas pelayanan, kepercayaan, dan lokasi terhadap loyalitas dengan kepuasan sebagai variabel intervening dengan studi pada pengguna handphone merek Samsung di Semarang. 
Hasil penelitian yang diperoleh mendapati bahwa bauran pemasaran berpengaruh positif dan signifikan terhadap kepuasan pelanggan, Kualitas Pelayanan berpengaruh positif dan signifikan terhadap kepuasan pelanggan, kepercayaan berpengaruh positif dan signifikan terhadap kepuasan pelanggan, lokasi berpengaruh positif dan tidak signifikan terhadap kepuasan pelanggan, bauran pemasaran berpengaruh positif dan signifikan terhadap loyalitas pelanggan, kualitas pelayanan berpengaruh positif dan signifikan terhadap loyalitas pelanggan, kepercayaan berpengaruh positif dan signifikan terhadap loyalitas pelanggan, lokasi berpengaruh positif dan signifikan terhadap loyalitas pelanggan, kepuasan pelanggan berpengaruh positif dan signifikan terhadap loyalitas pelanggan.

Setiawan (2013) meneliti tentang pengaruh strategi pemasaran dan kualitas produk terhadap kepuasan nasabah, dengan melakukan survey pada nasabah Bank BNI Syariah Cabang Cirebon. Hasil penelitian adalah strategi pemasaran dan kualitas produk terhadap kepuasaan nasabah di Bank BNI Syariah, dapat diketahui bahwa nilai Fhitung $(21,052)>$ Ftabel $(3,516)$. Dengan demikian bahwa strategi pemasaran dan kualitas produk secara bersama-sama berpengaruh terhadap kepuasaan nasabah. Dilihat dari hasil tabel Model Summary besarnya angka R-square $\left(\mathrm{r}^{2}\right)$ adalah 0,393, angka tersebut mempunyai pengertian bahwa pengaruh dari strategi pemasaran dan kualitas produk terhadap kepuasaan nasabah adalah 39,3\%. Sedangkan sisanya $61,7 \%$ dipengaruhi oleh faktor lain.

Tannady (2017) melakukan analisis pengaruh kualitas pelayanan terhadap kepuasan pelanggan, melalui studi kasus di NN Laundry, Jakarta Selatan, Hasil penelitian adalah factor-faktor tangibles, reliability, dan responsiveness berpengaruh secara signifikan terhadap kepuasan konsumen. Faktor-faktor assurance dan empathy tidak berpengaruh secara signifikan atas kepuasan konsumen.

Amilia dan Novianti (2016) meneliti pengaruh bauran pemasaran terhadap kepuasan konsumen pada Warung Kanasha di Kota Langsa. Hasil penelitian persamaan regresi linier berganda diperoleh: $\mathrm{KK}=2,709$ $+0,189$ Prod $-0,011 \mathrm{H}+0,041$ Prom $+0,278 \mathrm{~T}$ $+0,054 \mathrm{O}+0,081 \mathrm{LF}+0,223$. Bauran pemasaran yang terdiri dari produk, promosi, tempat, orang/karyawan, lingkungan fisik dan proses memberikan pengaruh positif terhadap kepuasan konsumen dan harga memberikan pengaruh negatif atas kepuasan konsumen. Koefisien determinasi $\left(\mathrm{R}^{2}\right)$ diperoleh sebesar 0,417 atau bila dipersentasekan $41,7 \%$ variabel produk, harga, promosi, tempat, orang/karyawan, lingkungan fisik dan proses memberikan pengaruh terhadap kepuasan konsumen pada Warung Kanasha di Kota Langsa; dan sisanya 58,3\% dipengaruhi oleh variabel-variabel lain yang tidak diteliti dalam penelitian ini. Uji t atau uji secara parsial untuk variabel produk secara parsial berpengaruh positif dan signifikan terhadap kepuasan konsumen, harga secara parsial berpengaruh negatif dan tidak signifikan atas kepuasan konsumen, promosi secara parsial memiliki pengaruh positif dan tidak signifikan terhadap kepuasan konsumen, tempat secara parsial berpengaruh positif dan signifikan atas kepuasan konsumen, orang/karyawan secara parsial berpengaruh positif dan tidak signifikan terhadap kepuasan konsumen, lingkungan fisik secara parsial berpengaruh positif dan tidak signifikan terhadap kepuasan konsumen, dan proses secara parsial berpengaruh positif dan signifikan terhadap kepuasan konsumen. Selanjutnya, uji F secara simultan atau bersama-sama produk, harga, promosi, tempat, orang/karyawan, lingkungan fisik dan proses berpengaruh signifikan terhadap kepuasan konsumen pada Warung Kanasha di Kota Langsal

Safrizal (2015) meneliti pengaruh harga dan kualitas pelayanan terhadap kepuasan konsumen pada Restoran Ayam Penyet Pak Ulis di Kota Langsa. Hasil penelitian KK = $0,620+0,801 \mathrm{H}+0,150 \mathrm{KP}$. Uji secara parsial (uji t), pada variabel harga, t-hitung > t-tabel yaitu $12,050>1,984$ dan dapat dinyatakan bahwa harga berpengaruh positif dan signifikan terhadap kepuasan konsumen pada Restoran Ayam Penyet Pak Ulis. Pada variabel kualitas pelayanan, $\mathrm{t}$-hitung $>\mathrm{t}$-tabel yaitu $2,174>1,984$ dan dapat dinyatakan 
bahwa kualitas pelayanan berpengaruh positif dan signifikan terhadap kepuasan konsumen pada Restoran Ayam Penyet Pak Ulis. Uji F menggunakan kriteria F-hitung dan F-tabel dapat diketahui bahwa perolehan diketahui Fhitung > F-tabel $(94,240>3,938)$ dan dapat dinyatakan bahwa variabel harga dan kualitas pelayanan secara simultan berpengaruh positif dan signifikan terhadap kepuasan konsumen pada restoran Ayam Penyet Pak Ulis. Koefisien determinasi $\left(\mathrm{R}^{2}\right)$ diperoleh sebesar 0,660 atau sebesar 66\% variabel harga dan kualitas pelayanan mempengaruhi kepuasan konsumen yang berbelanja pada Restoran Ayam Penyet Pak Ulis.

\section{Pengaruh Strategi Pemasaran terhadap Kepuasan Pelanggan}

Andaiyani (2015:2) menyatakan bahwa adanya hubungan antara stategi pemasaran dengan kepuasan pelanggan. Ia menyatakan bahwa dimensi strategi produk, harga, promosi, lokasi dan fasilitas dapat mempengaruhi variabel strategi pemasaran diuji secara parsial terhadap keputusan pelanggan maka hal ini terbukti bahwa variabel strategi pemasaran berpengaruh secara signifikan terhadap variabel kepuasa pelanggan.

\section{Pengaruh Pelayanan terhadap Kepuasan Pelanggan}

Menurut Anderson (dalam Anatan, 2010:70), adanya hubungan antara kualitas pelayanan dengan kepuasan pelanggan. Ia menyatakan perbaikan kualitas pelayanan akan menghasilkan kepuasan konsumen, oleh karenanya hubungan itu harus ditingkatkan.

\section{Hipotesis}

Berdasarkan teori/konsep dan penelitian terdahulu yang telah diuraikan, maka bisa dimunculkan hipotesis dalam penelitian ini adalah:

1. Strategi pemasaran berpengaruh terhadap kepuasan mahasiswa pada STIE Mahaputra Riau.

2. Pelayanan berpengaruh terhadap kepuasan mahasiswa pada STIE Mahaputra Riau.

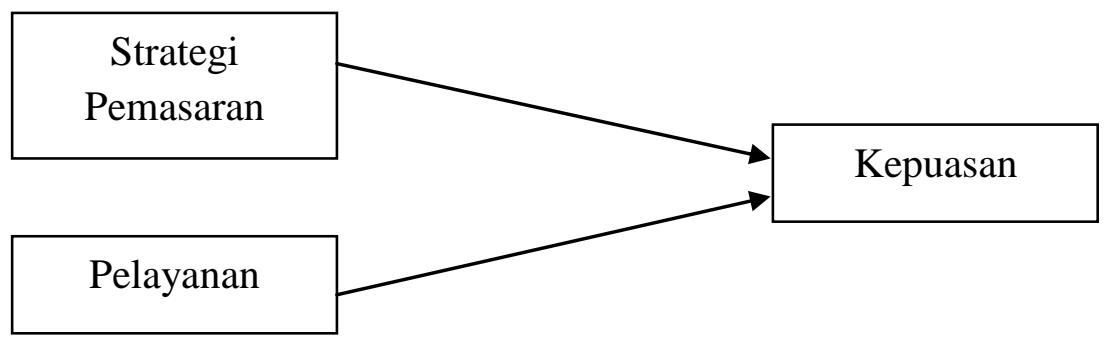

Gambar 1. Kerangka Pemikiran

\section{METODE PENELITIAN}

Sugiyono (2010:115) menyatakan bahwa populasi adalah wilayah generalisasi yang terdiri atas obyek atau subyek yang mempunyai kualitas dan karakteristik tertentu yang ditetapkan oleh peneliti untuk dipelajari dan kemudian ditarik kesimpulannya. Populasi pada penelitian ini adalah mahasiwa STIE Mahaputra Riau yang masuk pada Tahun 2018 sebanyak 150 orang mahasiswa.

Menurut Sugiyono (2010:116), sampel adalah bagian dari jumlah dan karakteristik yang dimiliki oleh populasi tersebut. Teknik pengambilan atau penentuan jumlah sampel menggunakan rumus Slovin dan didapatkan sebanyak 60 orang yang menjadi responden pada penelitian ini.

\section{Jenis dan Sumber Data}

Jenis dan sumber data penelitian ini terbagi atas dua bagian, yakni menggunakan data sekunder dan menggunakan data primer. Uraian masing-masing adalah sebagai berikut:

1. Data Primer merupakan data yang diperoleh dengan melakukan survey lapangan yang menggunakan semua metode pengumpulan data original. Data primer pada penelitian ini yaitu kuesioner penelitian (Kuncoro, 2009:148). 
2. Data Sekunder merupakan data yang dikumpulakan oleh lembaga pengumpulan data dan dipublikasikan pada masyarakat pengguna data. Data sekunder untuk penelitian ini terdiri dari buku, jurnal penelitian yang terkait dengan variabel yang diteliti (Kuncoro, 2009:148).

\section{Teknik Pengumpulan Data}

Menurut Sugiyono (2012:137), dilihat dari segi cara atau tehnik pengumpulan data, maka tehnik pengumpulan data dapat dilakukan dengan interview (wawancara), kuesioner (angket), observasi, dan gabungan ketiganya. Uraian dari masing-masing teknik tersebut adalah:

1. Interview (wawancara), digunakan sebagai tehnik pengumpulan data apabila peneliti ingin melakukakan studi pendahuluan untuk menemukan permasalahan yang harus diteliti, dan juga apabila peneliti ingin mengetahui hal-hal dari responden yang lebih mendalam dan jumlah respondennya sedikit/kecil.

2. Quesioner (angket) merupakan tehnik pengumpulan data yang dilakukan dengan cara memberi seperangkat pertanyaan atau pernyataan tertulis kepada para responden untuk dijawab. Kuesioner merupakan tehnik pengumpulan data yang efisien bila peneliti tahu dengan pasti variabel yang akan diukur dan dan tahu apa yang bisa diharapkan dari para responden.

3. Observasi, sebagai tehnik pengumpulan data mempunyai ciri yang spesifik dibandingkan dengan tehnik lain, yaitu wawancara dan kuesioner. Bila teknik wawancara dan kuesioner dilakukan selalu melalui komunikasi dengan orang, maka observasi tidak terbatas pada orang, tetapi juga objek-objek alam yang lain.

Untuk mengukur indikator kuesioner dalam penelitian menggunakan skala Likert dimana setiap jawaban yang tersedia diberi bobot nilai. Kriteria skor penilaian dengan skala Likert dalam penelitian ini adalah seperti dalam Tabel 1.
Tabel 1. Kriteria Skor Penilaian

\begin{tabular}{clc}
\hline No & \multicolumn{1}{c}{ Jawaban } & Skor \\
\hline 1 & Sangat Setuju (SS) & 5 \\
2 & Setuju (S) & 4 \\
3 & Cukup Setuju (CS) & 3 \\
4 & Tidak Setuju (TS) & 2 \\
5 & Sangat Tidak Setuju (STS) & 1 \\
\hline
\end{tabular}

Sumber: Sugiyono, 2012.

\section{Metode Analisis Data}

Teknik analisa data pada penelitian ini terdiri dari dua analisa data penelitian yaitu analisis data secara deskriptif dan analisis data secara inferensial.

Menurut Sugiyono (2011:206), analisis deskriptif adalah metode statistik yang digunakan untuk menganalisa data dengan cara mendeskripsikan atau menggambarkan data yang telah terkumpul sebagaimana adanya dan tanpa bermaksud membuat kesimpulan yang berlaku untuk umum atau generalisasi.

\section{Uji Validitas dan Reliabilitas}

Uji validitas digunakan untuk mengukur sah atau valid tidaknya suatu kuesioner. Kuesioner akan dikatakan valid apabila pertanyaan di dalam kuesioner mampu mengungkapkan sesuatu yang akan diukur oleh kuesioner tersebut. Validitas dalam penelitian ditentukan oleh proses pengukuran yang akurat. Uji validitas digunakan untuk mengetahui apakah item-item yang ada didlam kuesioner mampu mengukur peubah yang didapatkana dalam penelitian ini (Ghozali, 2013:52).

Uji validitas dalam penelitian ini menggunakan uji korelasi person product moment dengan ketentuan jika nilai $\mathrm{r}_{\text {hitung }}>$ nilai $r_{\text {tabel }}$ maka item pernyataan dinyatakan valid. Perhitungan dilakukan dengan cara membandingkan nilai $r_{\text {hitung }}$ dengan $r_{\text {tabel }}$ untuk degree of freedom $(\mathrm{df})=\mathrm{n}-2$; dalam hal ini $\mathrm{n}$ adalah jumlah sampel.

Uji reliabiitas merupakan alat untuk mengukur suatu kuesioner yang merupakan indikator dari variabel atau konstruk. Kuesioner dikatakan handal ketika jawaban 
seseorang terhadap pertanyaan adalah konsisten atau stabil dari waktu ke waktu. Data yang reliabel dalam instrument peneliian berarti data tersebut dapat dipercaya. Untuk mengukur reliabilitas konsistensi internal peneliti dapat menggunakan tehnik Cronbach alpha, dimana besarnya nilai alpha yang dihasilkan dibandingkan dengan $>0.60$.

Pengambilan keputusan berdasarkan pada jika nilai alpha melebihi 0,60 maka pertanyaan variabel tersebut tidak reliable; dan jika nilai alpha kurang dari 0,60 maka pertanyaan variabel tersebut reliable.

\section{Analisis Regresi Berganda}

Metode analisis data secara inferensial yang digunakan pada penelitian ini adalah regresi berganda. Menurut Ghozali (2013:96), analisis regresi digunakan untuk mengukur kekuatan hubungan antara dua variabel atau lebih, juga menunjukkan arah atau hubungan antara variabel dependen dan independen.

Analisis regresi linear berganda adalah hubungan antara dua atau lebih variabel independen (X) dengan variabel dependen (Y). analisis ini untuk memprediksi nilai dari variabel dependen apabla nilai variabel independen mengalami kenaikan atau penurunan dan untuk mengetahui arah hubungan antara variabel independen dan variabel dependen apakah masing-masing variabel independen berhubungan positif atau negatif.

Perhitungan regresi linear berganda dihitung sebagai berikut:

$$
\mathrm{Y}=\mathrm{a}+\mathrm{b}_{1} \mathrm{X}_{1}+\mathrm{b}_{2} \mathrm{X}_{2}+\mathrm{e}
$$

Keterangan:

$\mathrm{Y}=$ Kepuasan Pelanggan

$\mathrm{a}=$ Konstanta

$\mathrm{b}_{1} \mathrm{~b}_{2}=$ Koefisien Berganda

$\mathrm{e}=$ Error

$\mathrm{X}_{1}=$ Strategi Pemasaran

$\mathrm{X}_{2}=$ Pelayanan

\section{Uji Asumsi Klasik}

Untuk menunjukkan apakah model regresi benar-benar menunjukan hubungan yang signififkan dan representatif maka model tersebut harus memenuhi uji asumsi klasik. Uji asumsi klasik terdiri dari uji normalitas, uji heterokedastisitas, uji multikolinieritas, dan uji autokorelasi. Uraian masingmasing uji tersebut adalah sebagai berikut:

a. Uji Normalitas.

Uji normalitas dilakukan untuk mengetahui apakah dalam model regresi variabel pengganggu ataupun residual memiliki distribusi normal. Untuk mengetahui apakah data berdistribusi normal maka bisa dilakukan dengan menggunakan analisis grafik, yaitu melihat penyebaran data (titik) pada sumbu diagonal dari grafik atau dengan melihat histogram dari residualnya (Nyoto, 2015:161).

b. Uji Heteroskedastisitas.

Uji heteroskedastisitas bertujuan untuk menguji apakah dalam model regresi terjadi ketidaksamaan varians dan residual satu pengamatan ke pengamatan yag lain. Jika varians dari residual satu pengamatan kepengamatan yang lain tetap, maka disebut homoskedastisitas dan jika berbeda disebut heteroskedastisitas. Uji heteroskedastisitas dilakukan dengan menggunakan uji Glesjer, yang dilakukan dengan meregresikan nilai absolut residual yang diperoleh dari model regresi sebagai variabel dependen terhadap semua variabel independen dalam model regresi (Nyoto, 2015:160).

c. Uji Multikolinearitas.

Uji multikolinearitas dilakukan dengan tujuan untuk menguji apakah dalam model regresi ditemukan adanya korelasi antara variabel-variabel bebas (independen). Dalam model regresi yang baik seharusnya tidak terjadi korelasi di antara variabel-variabel bebas yang di analisis. Uji multikolinearitas dilakukan dengan melihat nilai tolerance dan Varian Inflation Factor (VIF) dari hasil analisis dengan menggunakan SPSS. Apabila nilai tolerance value lebih tinggi daripada 0,10 atau VIF lebih kecil daripada 10 maka disimpulkan tidak terjadi multikolinearitas (Nyoto, 2015:160). 


\section{Pengujian Hipotesis}

Untuk memperoleh simpulan dari penelitian ini, maka terlebih dahulu dilakuan pengujian hipotesis secara individual (parsial) maupun secara menyeluruh (simultan). Uraian mengenai masing-masing teknik uji hipotesis tersebut adalah sebagai berikut:

a. Pengujian Hipotesis secara Parsial (Uji t). Menurut Nyoto (2015:154), penguji secara parsial dilakukan untuk mengetahui pengaruh yang diberikan masing-masing variabel bebas terhadap variabel terkait secara individual (mandiri), dan juga melihat variabel bebas yang mempunyai pengaruh yang paling kuat terhadap variabel terikat. Uji parsial ini dilakukan dengan melihat kriteria:

- Jika $t_{\text {hitug }}>t_{\text {tabel }}$, maka Ho ditolak dan Ha diterima, berati variabel bebas secara parsial memberikan pengaruh yang signifikan terhadap variabel terikat.

- Jika $t_{\text {hitung }}<\mathrm{t}_{\text {tabel, }}$ maka Ho diterima dan Ha ditolak, berati variabel bebas secara parsial tidak memberkan pengaruh yang signifikan terhadap variabel terkait.

b. Pengujian Hipotesis secara Simultan (Uji F).

Uji $F$ dilakukan untuk menguji apakah variabel-variabel secara simultan berpengaruh terhadap variabel dependen. Uji $\mathrm{F}$ ini dilakukan dengan membandingkan nilai $F_{\text {hitung dan }} F_{\text {tabel }}$ (Ghozali, 2013:127).

Uji statistik $F$ adalah dengan membandingkan nilai $F_{\text {hitung }}$ dengan $F_{\text {tabel }}$ dengan melihat kriteria:

- Jika $\mathrm{F}_{\text {hitung }}>\mathrm{F}_{\text {tabel, }}$ maka Ho ditolak dan Ha diterima, maka variabel bebas secara simultan memberikan pengaruh terhadap variabel terikat.

- Jika $F_{\text {hitung }}<\mathrm{F}_{\text {tabel }}$, maka Ho diterima dan Ha ditolak, maka variabel bebas secara simultan tidak memberikan pengaruh terhadap varaibel terikat.

\section{Koefisien Determinasi $\left(R^{2}\right)$}

Koefisien determinasi digunakan untuk mengetahui persentase pengaruh variabel independen, yaitu variabel $\mathrm{X}$ terhadap perubahan variabel dependen yaitu variabel Y. Secara sederhana, koefisien determinasi selalu dikaitkan dengan seberapa besar kemampuan variabel bebas menjelaskan varians dari variabel terikat. Untuk upaya mengetahui besaran sumbangan (kontribusi) variabel independen terhadap variabel dependen maka dapat dilihat dengan mencari nilai koefisien determinasi atau penentu.

\section{HASIL ANALISIS}

Penelitian ini menggunakan sampel penelitian sebesar 60 orang responden yang menjadi sampel penelitian. Karakteristik responden pada penelitian ini yang terdiri dari jenis kelamin dan jurusan atau program studi, dirangkum dalam Tabel 2 dan Tabel 3.

Berdasarkan pada Tabel 2 yaitu berbasis jenis kelamin maka dapat diketahui responden berjenis kelamin laki-laki adalah lebih banyak jumlahnya (43 orang atau $71 \%$ ) dibandingkan dengan responden berjenis kelami perempuan (17 orang atau 29\%).

Berdasarkan pada Tabel 3 yaitu berbasis program studi, maka dapat diketahui responden yang berasal dari Prodi Manajemen adalah lebih banyak jumlahnya (43 orang atau $71 \%$ ) dibandingkan dengan responden yang berasal dari Prodi Akuntansi (17 orang atau $29 \%)$.

Tabel 2. Responden Berdasarkan Jenis Kelamin

\begin{tabular}{ccc}
\hline Jenis Kelamin & Jumlah (Orang) & Persentase (\%) \\
\hline Laki-Laki & 43 & 71 \\
Perempuan & 17 & 29 \\
\hline Total & 60 & 100 \\
\hline
\end{tabular}

Sumber: Data primer diolah, 2018. 
Tabel 3. Responden Berdasarkan Program Studi

\begin{tabular}{ccc}
\hline Program Studi & Jumlah (Orang) & Persentase (\%) \\
\hline Manajemen & 43 & 71 \\
Akuntansi & 17 & 29 \\
\hline Total & 60 & 100 \\
\hline
\end{tabular}

Sumber: Data primer diolah, 2018.

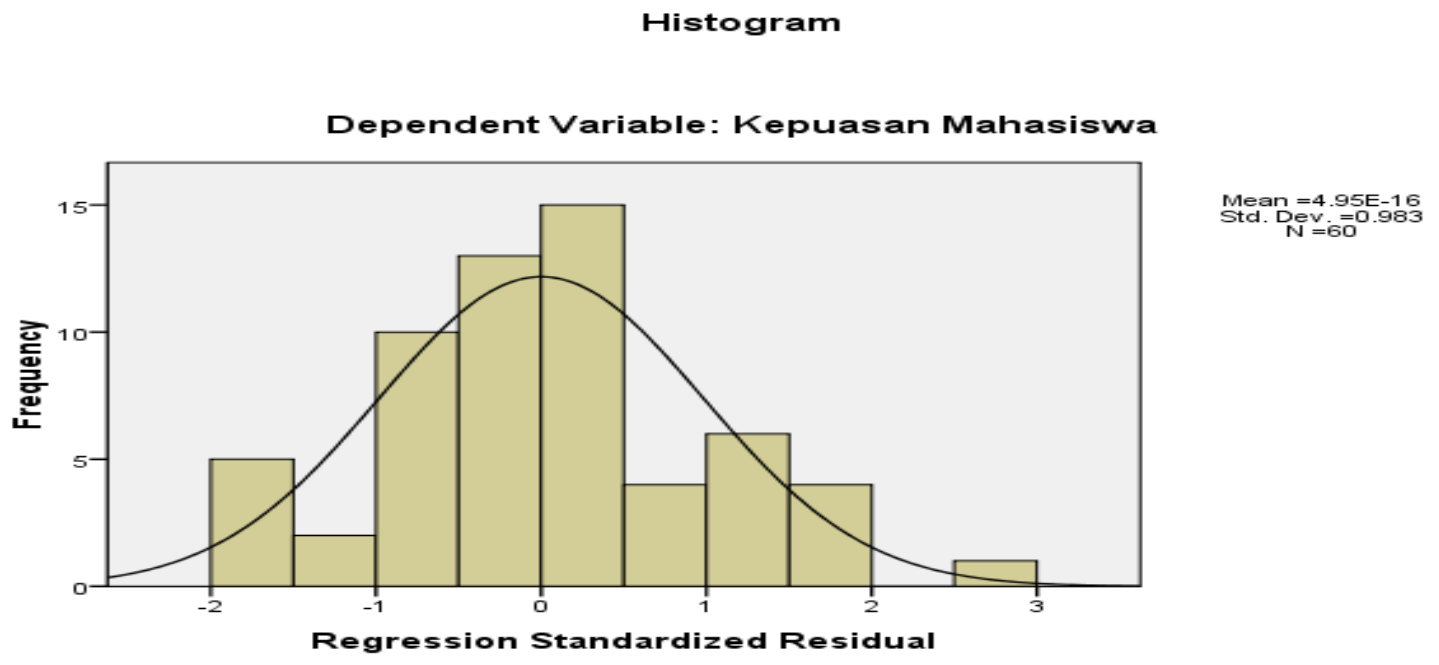

Gambar 2. Hasil Histogram untuk Uji Normalitas

Sumber: Data primer diolah, 2018.

\section{Uji Asumsi Klasik}

Uji asumsi klasik merupakan bagian yang terpenting pada saat regresi linier berganda. Dalam asumsi klasik dapat terbagi atas beberapa bagian, diantaranya adalah uji normalitas, uji heterokedastisitas, dan uji multikolinieritas.

\section{Uji Normalitas}

Uji normalitas dilakukan untuk mengetahui apakah dalam model regresi variabel pengganggu atau residual memiliki distribusi normal. Untuk mengetahui apakah data berdistribusi normal bisa dilakukan dengan menggunakan analisis grafik, yaitu melihat penyebaran data (titik) pada sumbu diagonal dari grafik atau dengan melihat histogram dari residualnya (Nyoto, 2015:161). Uji normalitas dapat diketahui dengan menggunakan grafik baik histogram maupun Kolmogrov-Smirnov (K-S). Hasil dari uji normalitas ditunjukkan di dalam Gambar 2.

Berdasarkan pada Gambar 2, diperoleh uji normalitas menghasilkan grafik Histogram berbentuk lonceng dengan tidak mengalami kemencengan. Hal ini menyimpulkan model penelitian ini terbebas dari ketidaknormalan data yang digunakan.

Lebih jauh, berdasarkan Gambar 3, hasil pengolahan menggunakan scatterplot atas uji normalitas menghasilkan titik-titik menyebar mendekati garis diagonal. Dengan demikian, berdasarkan scatterplot tersebut dapat disimpulkan juga bahwa model penelitian ini terbebas dari ketidaknormalan data.

Berdasarkan hasil uji KolmogorovSmirnov (KS) yang dirangkum dalam Tabel 4, dapat diketahui nilai dari Asymp.sig sebesar 0.901 adalah lebih besar dari 0,05. Dengan demikian, hasil uji ini juga menyimpulkan bahwa data penelitian ini terdistribusi normal. 


\section{Normal P-P Plot of Regression Standardized Residual}

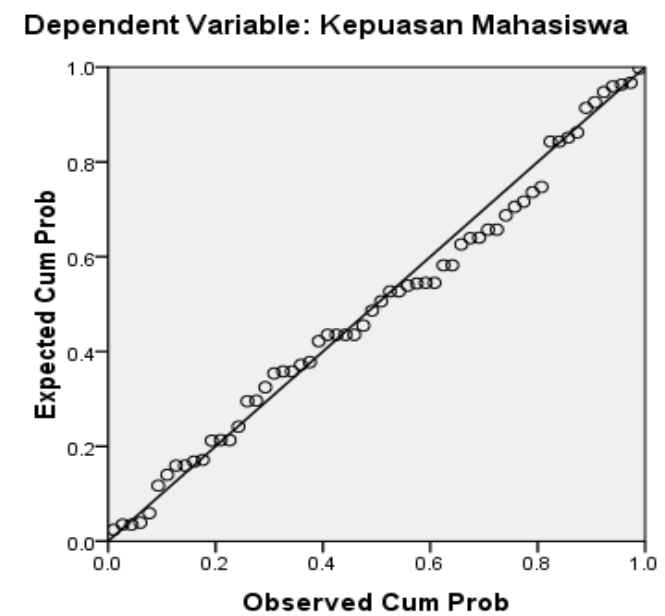

\section{Gambar 2. Hasil Scatterplot untuk Uji Normalitas}

Sumber: Data primer diolah, 2018.

Tabel 4. Hasil Kolmogorov-Smirnof (KS) untuk Uji Normalitas

\begin{tabular}{lcc}
\hline & \multicolumn{2}{c}{$\begin{array}{c}\text { Unstandardized } \\
\text { Residual }\end{array}$} \\
\hline Asymp. Sig. (2-tailed) & .901 \\
\hline a. Test distribution is Normal. &
\end{tabular}

Sumber: Data primer diolah, 2018.

\section{Uji Heterokedastisitas}

Uji heteroskedastisitas bertujuan untuk menguji apakah dalam model regresi terjadi ketidaksamaan varians dan residual satu pengamatan ke pengamatan yang lain. Jika varians dari residual satu pengamatan ke pengamatan yang lain tetap, maka disebut homoskedastisitas; dan jika berbeda disebut heteroskedastisitas. Uji heteroskedastisitas dilakukan menggunakan uji Glesjer, yang dilakukan dengan meregresikan nilai absolut residual yang diperoleh dari model regresi sebagai variabel dependen terhadap semua variabel independen dalam model regresi (Nyoto, 2015:160). Hasil uji Glejser atas heterokedastisitas ditunjukkan dalam Tabel 5.

Berdasarkan pada hasil uji Glejser dalam Tabel 5 diketahui bahwa nilai dari signifikansi di atas 0.05 ; sehingga dinyatakan bahwa model penelitian ini terbebas dari masalah heterokedastisitas.

Tabel 5. Hasil Glejser untuk Uji Heterokedastisitas

\begin{tabular}{clrr}
\hline \multicolumn{1}{c}{ Model } & & $\mathrm{t}$ & \multicolumn{2}{c}{ Sig. } \\
\hline \multirow{2}{*}{1} & (Constant) & 6.308 & .000 \\
& Strategi Pemasaran & 1.864 & .567 \\
& Pelayanan & -3.312 & .522 \\
\hline
\end{tabular}

a. Dependen Variable: Absut

Sumber: Data primer diolah, 2018. 
Tabel 6. Hasil Uji Multikolinieritas

\begin{tabular}{|c|c|c|c|}
\hline \multirow{2}{*}{ Model } & & \multicolumn{2}{|c|}{ Collinearity Statistics } \\
\hline & & Tolerance & VIF \\
\hline \multirow[t]{3}{*}{1} & (Constant) & & \\
\hline & Strategi Pemasaran & .127 & 7.878 \\
\hline & Pelayanan & .127 & 7.878 \\
\hline
\end{tabular}

Sumber: Data primer diolah, 2018.

Tabel 7. Hasil Uji Hipotesis Parsial (Uji $t$ )

\begin{tabular}{llrr}
\hline \multicolumn{1}{c}{ Model } & & $\mathrm{t}$ & \multicolumn{1}{c}{ Sig. } \\
\hline \multirow{2}{*}{1} & (Constant) & 6.447 & .000 \\
& Strategi Pemasaran & 3.854 & .000 \\
& Pelayanan & 2.815 & .007 \\
\hline
\end{tabular}

a. Dependent Variable: Kepuasan mahasiswa

Sumber: Data primer diolah, 2018.

\section{Uji Multikolinieritas}

Uji multikolinearitas bertujuan untuk menguji apakah dalam model regresi ditemukan adanya korelasi antara variabel bebas (independen). Dalam model regresi yang baik seharusnya tidak terjadi korelasi diantara variabel bebas. Uji multikolinearitas dilakukan dengan melihat nilai tolerance dan Varian Inflation Factor (VIF) dari hasil analisis dengan menggunakan SPSS. Apabila nilai tolerance value lebih tinggi daripada 0,10 atau VIF lebih kecil daripada 10 maka dapat disimpulkan tidak terjadinya masalah multikolinearitas (Nyoto, 2015:160). Uji multikolineritas dapat diketahui dengan nilai tolerance maupun nilai VIF. Hasil dari uji multikolinieritas atas model penelitian ini ditunjukkan dalam Tabel 6.

Berdasarkan Tabel 6 diperoleh bahwa pada hasil uji multikolineritas menghasilkan nilai strategi pemasaran dan pelayanan dengan Tolerance $>0.1$ dan VIF $<10$. Dengan demikian, model penelitian ini dinyatakan terbebas dari multikolinieritas.

\section{Pengujian Hipotesis}

Pengujian hipotesis pada penelitian ini terdiri dari dua uji, yaitu uji parsial dan uji simultan. Hasil pengolahan untuk masingmasing tipe uji hipotesis tersebut diuraikan sebagai berikut.

\section{Uji Parsial}

Menurut Nyoto (2015:154), pengujian secara parsial dilakukan untuk mengetahui pengaruh yang diberikan masing-masing variabel bebas terhadap variabel terkait secara individual (mandiri); dan juga melihat variabel bebas yang mempunyai pengaruh yang paling kuat terhadap variabel terikat.

Berdasarkan Tabel 7 diperoleh bahwa hasil uji parsial ini menyatakan bahwa:

- Strategi pemasaran pada $t_{\text {hitung }}$ sebesar 3.854 dan nilai $t_{\text {tabel }}$ sebesar 1.67203; dengan signifikansi sebesar 0.000 . Hasil ini menunjukkan bahwa strategi pemasaran berpengaruh parsial secara signifikan terhadap kepuasan mahasiswa pada STIE Mahaputra Riau.

- Pelayanan pada $t_{\text {hitung }}$ sebesar 2.815 dan nilai $t_{\text {tabel }}$ sebesar 1.67203; dengan signifikansi sebesar 0.000 . Hasil ini menunjukkan bahwa aspek pelayanan berpengaruh parsial secara signifikan terhadap kepuasan mahasiswa pada STIE Mahaputra Riau.

\section{Uji Simultan}

Uji F dilakukan untuk menguji apakah variabel secara simultan berpengaruh terhadap variabel dependen. Uji F ini dilakukan dengan membandingkan antara nilai $F_{\text {hitung }}$ dan $F_{\text {tabel }}$ 
(Ghozali, 2013:127). Berdasarkan Tabel 8 diperoleh bahwa hasil uji simultan atas model penelitian ini menyatakan bahwa nilai $\mathrm{F}_{\text {hitung }}$ sebesar 169.599 dan nilai $\mathrm{F}_{\text {tabel }}$ sebesar 2.77. Hasil ini menyatakan strategi pemasaran dan pelayanan secara simultan berpengaruh signifikan terhadap kepuasan mahasiswa STIE Mahaputra Riau.

\section{Koefisien Determinasi}

Koefiesien determinasi berfungsi untuk mengetahui seberapa besarnya kemampuan variabel terikat dalam menjelaskan variabel terikatnya. Berdasarkan Tabel 9, nilai dari koefiesien determinasi dapat diketahui sebesar 92,\% yang artinya bahwa kepuasan mahasiswa dapat dijelaskan oleh strategi pemasaran dan pelayanan sebesar 92\%; sedangkan sisanya dipengaruhi oleh faktor lain yang tidak diteliti dalam penelitian ini.

\section{Pembahasan}

Berdasarkan hasil yang diperoleh dalam penelitian ini, maka bisa dibahas lebih lanjut.

\section{Pengaruh Strategi Pemasaran terhadap Kepuasan Mahasiswa}

Strategi pemasaran berpengaruh parsial terhadap kepuasan mahasiswa pada STIE Mahaputra Riau. Hal ini sesuai dengan pendapat Andaiyani (2015:2) yang mana menyatakan bahwa adanya hubungan antara stategi pemasaran dan kepuasan pelanggan. Ia menyatakan bahwa dimensi strategi produk, harga, promosi, lokasi dan fasilitas dapat mempengaruhi variabel strategi pemasaran diuji secara parsial terhadap keputusan pelanggan; maka hal ini terbukti bahwa variabel strategi pemasaran berpengaruh secara segnifikan terhadap variabel kepuasa pelanggan.

\section{Tabel 8. Hasil Uji Hipotesis Simultan (Uji F)}

\begin{tabular}{clccc}
\hline Model & & F & Sig. \\
\hline 1 & Regression & 169.599 & $.000^{\mathrm{a}}$ \\
& Residual & & \\
& Total & & \\
\hline
\end{tabular}

a. Predictors: (Constant), Pelayanan, Strategi Pemasaran

b. Dependent Variable: Kepuasan mahasiswa

Sumber: Data primer diolah, 2018.

Tabel 9. Hasil Koefisien Determinasi

\begin{tabular}{cccc}
\hline \multicolumn{2}{c}{$\mathrm{R}$} & \multicolumn{2}{c}{ R Square } \\
\hline & 1 & $.925^{\mathrm{a}}$ & .856 \\
\hline
\end{tabular}

a. Predictors: (Constant), Pelayanan, Strategi Pemasaran

b. Dependent Variable: Kepuasan mahasiswa

Sumber: Data primer diolah, 2018.

\section{Pengaruh Pelayanan terhadap Kepuasan Mahasiswa}

Pelayanan berpengaruh parsial terhadap kepuasan mahasiswa pada STIE Mahaputra Riau, hal ini sesuai dengan pendapat Menurut Anderson (dalam Anatan, 2010:70) bahwa adanya hubungan antara kualitas pelayanan dengan kepuasan pelanggan. Ia menyatakan bahwa perbaikan kualitas pelayanan akan menghasilkan kepuasan konsumen, oleh karena itu maka hubungan tersebut harus ditingkatkan.

\section{KESIMPULAN}

Berdasarkan hasil-hasil yang diperoleh dalam penelitian ini, maka dapat ditarik beberapa kesimpulan sebagai berikut:

1. Strategi pemasaran berpengaruh terhadap kepuasan mahasiswa pada STIE Mahaputra Riau. 
2. Pelayanan berpengaruh terhadap kepuasan mahasiwa pada STIE Mahaputra Riau.

3. Nilai kofiesien determinasi menunjukkan 92,\% yang artinya bahwa kepuasan mahasiswa dapat dijelaskan oleh strategi pemasaran dan pelayanan sebesar 92\%; sedangkan sisanya dipengaruhi oleh factor-faktor lain yang tidak diteliti pada penelitian ini.

\section{DAFTAR PUSTAKA}

Amilia, S. dan Novianti, A. 2016. Pengaruh Bauran Pemasaran terhadap Kepuasan Konsumen pada Warung Kanasha di Kota Langsa. Jurnal Manajemen dan Keuangan. Vol. 5, No. 1, hal. 459468.

Andayani. 2015. Pengaruh Strategi Pemasaran dan Kualitas Pelayanan terhadap Kepuasan Pelanggan di Pauw's Kopitiam Sungailiat Kabupaten Bangka. Bangka Belitung: Jurusan Manajemen Fakultas Ekonomi Universitas Bangka Belitung.

Herlambang, S. 2016. Manajemen Pelayanan Kesehatan Rumah Sakit: Cara Mudah Memahami Manajemen Pelayanan di Rumah Sakit dan Organisasi Pelayanan Kesehatan Lainnya. Yogyakarta: Gosyen Publishing.

Kuncoro, M. 2009. Metodologi Penelitian

Manajemen. Bandung. PT. Remaja Rosdakarya.
Lupiyoadi, R. dan Hamdani, A. 2016. Manajemen Pemasaran Jasa. Edisi 2. Jakarta: Salemba Empat.

Nyoto. 2015. Metodologi Penelitian: Teori dan Aplikasi. Pekanbaru: UR Press.

Safrizal. 2015. Pengaruh Harga dan Kualitas Pelayanan terhadap Kepuasan Konsumen pada Restoran Ayam Penyet Pak Ulis di Kota Langsa. Jurnal Manajemen dan Keuangan. Vol. 4, No. 1, hal. 214-224.

Setiawan, M.D. 2013. Pengaruh Strategi Pemasaran dan Kualitas Produk terhadap Kepuasan Nasabah (Survey pada Nasabah Bank BNI Syariah Cabang Cirebon. Skripsi. Cirebon: Jurusan Muamalat Ekonomi Perbankan Islam (MEPI) Fakultas Syariah Institut Agama Islam Negeri Syekh Nurjati Cirebon.

Sugiyono. 2012. Metodologi Penelitian Kualitatif dan Kuantitatif. Bandung: CV. Alfabeta.

Supriyanto dan Ernawaty. 2010. Pemasaran Industri Jasa Kesehatan. Yogyakarta: Andi.

Tjiptono, F. 2008. Strategi Pemasaran. Edisi Ketiga. Yogyakarta: Andi.

Tjiptono, F. dan Chandra, G. 2012. Pemasaran Strategik. Edisi Ketiga. Yogyakarta: Andi

Wijaya. 2011. Manajemen Kualitas Jasa. Cetakan Kesatu. Jakarta: Indeks. 